\title{
Citricoccus alkalitolerans sp. nov., a novel actinobacterium isolated from a desert soil in Egypt
}

\author{
Correspondence \\ Chang-Jin Kim \\ changjin@kribb.re.kr or \\ wjli@ynu.edu.cn
}

\author{
Wen-Jun Li ${ }^{1,2}$ Hua-Hong Chen, ${ }^{1,3}$ Yu-Qin Zhang, ${ }^{1}$ Chang-Jin Kim, ${ }^{2}$ \\ Dong-Jin Park, ${ }^{2}$ Jae-Chan Lee, ${ }^{2}$ Li-Hua $\mathrm{Xu}^{1}$ and Cheng-Lin Jiang ${ }^{1}$
}

\author{
${ }^{1}$ The Key Laboratory for Microbial Resources of Ministry of Education, P. R. China, Laboratory \\ for Conservation and Utilization of Bio-Resources, Yunnan Institute of Microbiology, Yunnan \\ University, Kunming, Yunnan, 650091, P. R. China \\ ${ }^{2}$ Korea Research Institute of Bioscience and Biotechnology, 52 Oeundong, Yusong, Daejeon \\ 305-333, Republic of Korea \\ ${ }^{3}$ Department of Chemistry, Chuxiong Normal College, Chuxiong, Yunnan, 675000, P. R. China
}

The genus Citricoccus was proposed by Altenburger et al. (2002a) with a single species, Citricoccus muralis. Its representative strain was isolated from a medieval wall painting and comprises Gram-positive, non-motile, nonspore-forming coccoid cells and the aerobic type of metabolism. In this report, we present the description of the second species of the genus, for which we propose the name Citricoccus alkalitolerans sp. nov.

Strain YIM $70010^{\mathrm{T}}$ was isolated from a desert soil sample collected in eastern Egypt by using medium recommended by Sato et al. (1983) for isolation of alkaliphilic and alkalineresistant micro-organisms. Sodium carbonate was sterilized separately and then added to the medium. The $\mathrm{pH}$ of the medium was $10-10 \cdot 5 ; \mathrm{NaHCO}_{3} / \mathrm{Na}_{2} \mathrm{CO}_{3}$ buffer was used to adjust the $\mathrm{pH}$. Strain YIM $70010^{\mathrm{T}}$ was cultivated aerobically

Published online ahead of print on 19 July 2004 as DOI 10.1099/ ijs.0.63237-0.

The GenBank/EMBL/DDBJ accession number for the $16 \mathrm{~S}$ rRNA gene sequence of strain YIM $70010^{\top}$ is AY376164.

An electron micrograph of a cell of strain YIM $70010^{\top}$ and a dendrogram showing the relationship of the strain with its nearest phylogenetic neighbours are available as supplementary material in IJSEM Online. at $28{ }^{\circ} \mathrm{C}$ for 1 week. Cells for biochemical and molecular systematic analyses were grown in shake flasks (at about 150 r.p.m.) of trypticase soy broth medium ( $\mathrm{pH} 8 \cdot 0-9 \cdot 0)$ at $28{ }^{\circ} \mathrm{C}$ for 1 week. Stock cultures were maintained at $4{ }^{\circ} \mathrm{C}$ using modified Sato's slants and as glycerol suspensions $(20 \%, \mathrm{v} / \mathrm{v})$ at $-20^{\circ} \mathrm{C}$.

Strain YIM $70010^{\mathrm{T}}$ was grown on PYES medium (Altenburger et al., 2002b) for observation of the cell and colony morphology. The growth temperature was tested at $4,10,20,28,37,40$ and $45^{\circ} \mathrm{C}$ on the same medium. Motility of cells and $\mathrm{pH}$ and $\mathrm{NaCl}$ tolerance of the strain were determined as described by Altenburger et al. (2002a, b). Metabolic properties were determined using API Coryne and API ID $32 \mathrm{E}$ test kits (bioMérieux) according to the manufacturer's instructions. Other physiological and biochemical tests were performed as described previously (Shirling \& Gottlieb, 1966).

Strain YIM $70010^{\mathrm{T}}$ was an aerobic, Gram-positive, nonmotile, non-spore-forming coccus, of about $0 \cdot 5-0 \cdot 8 \mu \mathrm{m}$ in diameter (Fig. A, available as supplementary material in IJSEM Online). Colonies of strain YIM $70010^{\mathrm{T}}$ on PYES medium were similar to those of C. muralis DSM $14442^{\mathrm{T}}$. Growth was observed at initial $\mathrm{pH}$ values of between $5 \cdot 5$ and 
$12 \cdot 0$, with the optimum at $\mathrm{pH} 8 \cdot 0-9 \cdot 0$. Other physiological and biochemical properties are given in Table 1 and in the species description.

The qualitative analyses of amino acids and peptides in peptidoglycan hydrolysates were carried out as described by Schleifer (1985) and Schleifer \& Kandler (1972) with the modification that TLC on cellulose was applied instead of paper chromatography. The $\mathrm{N}$ terminus of the interpeptide bridge was determined by dinitrophenylation according to Schleifer (1985). The quantitative analysis of amino acids in the total hydrolysates was done by GC and GC-MS as described by MacKenzie (1987) and Groth et al. (1996).

Menaquinones were isolated using the methods of Minnikin et al. (1984) and separated by HPLC (Kroppenstedt et al., 1981; Kroppenstedt, 1982). Polar lipids were extracted, examined by two-dimensional TLC and identified using published procedures (Minnikin et al., 1984). Fatty acid analysis was performed using standard methods (Sasser, 1990) and results were compared with the database of fatty acids in the MIDI Sherlock Microbial Identification system (MIDI Inc.).

Table 1. Distinctiveness of physiological and biochemical characteristics of strain $\mathrm{YIM} 70010^{\top}$ and C. muralis DSM $14442^{\top}$

The following phenotypic characteristics are the same for both strains. Gram-positive, non-motile, non-spore-forming coccoid cells. Catalase-positive and oxidase-negative. Urease, tyrosinase, Voges-Proskauer test, $\mathrm{H}_{2} \mathrm{~S}$ production and indole production are negative. Tweens 20 and 80, casein and starch are not decomposed. Nitrate is not reduced to nitrite. Activities for lipase and $\alpha$-glucosidase are positive. Negative for ornithine decarboxylase, arginine dihydrolase, $\beta$-glucuronidase, $\alpha$ - and $\beta$-galactosidase, $N$ acetyl- $\beta$-glucosaminidase and $\beta$-glucosidase. The following substrates are utilized by both strains as sole carbon sources for growth: glucose, galactose, sucrose, arabinose, mannose, mannitol, maltose, starch, xylose, ribose, cellobiose, salicin, sorbitol, lactose, dextrin and lysine. $N$-Acetyl- $\alpha$-glucosamine, L-alanine, $\beta$-alanine, L-histidine, L-ornithine and L-tryptophan are not utilized.

\begin{tabular}{|lcc|}
\hline Characteristic & YIM $\mathbf{7 0 0 1 0}^{\mathbf{T}}$ & DSM $\mathbf{1 4 4 4 2}^{\mathbf{T}}$ \\
\hline $\mathrm{pH}$ range for growth & $5 \cdot 5-12$ & $6-10$ \\
$\mathrm{NaCl}$ range for growth (\%) & $0-15$ & $0-10$ \\
Gelatin liquefaction & - & + \\
Methyl red & - & + \\
Lysine decarboxylase & - & + \\
-Maltosidase & - & + \\
Carbon and nitrogen utilization & & \\
$\quad$ Fructose & - & - \\
Amygdalin & + & - \\
Glycine & + & + \\
Arginine & - & $68^{*}$ \\
G + C content (mol\%) & $63 \cdot 8$ & \\
\end{tabular}

*Value for C. muralis was taken from Altenburger et al. (2002a).
The peptidoglycan of strain YIM $70010^{\mathrm{T}}$ contained Ala, Gly, Glu and Lys in a molar ratio of $1 \cdot 6: 1 \cdot 2: 2 \cdot 5: 1 \cdot 0$. Labelling by using 1 -fluoro-2,4-dinitrobenzene revealed that glutamic acid represents the amino terminus of the interpeptide bridge. From these results and the two-dimensional TLC peptide pattern of partial cell-wall hydrolysates (data not shown), it was concluded that the peptidoglycan type of strain YIM $70010^{\mathrm{T}}$ was Lys-Gly-Glu, variation $\mathrm{A} 4 \alpha$ (Schleifer \& Kandler, 1972) (type A11.42 or A11.56 according to the DSMZ, 2001). Other chemotaxonomic characteristics of the strain are presented in the species description.

Genomic DNA was isolated and purified by the method of Marmur (1961). The DNA G + C base content of strain YIM $70010^{\mathrm{T}}$ was measured as $63 \cdot 8 \mathrm{~mol} \%$ by using the thermal denaturation method (Marmur \& Doty, 1962).

The 16S rRNA gene sequence of the strain was amplified by PCR using conserved primers close to the $3^{\prime}$ and $5^{\prime}$ ends of the gene as described previously (Cui et al., 2001). Multiple alignments with sequences of actinobacteria of the family Micrococcaceae and calculations of levels of sequence similarity were carried out using CLUSTAL_X (Thompson et al., 1997). A phylogenetic tree was reconstructed using the neighbour-joining method of Saitou \& Nei (1987) from $K_{\text {nuc }}$ values (Kimura, 1980, 1983). The topology of the phylogenetic tree was evaluated by using the bootstrap resampling method of Felsenstein (1985) with 1000 replicates.

An almost-complete 16S rRNA gene sequence (1480 bp) for strain YIM $70010^{\mathrm{T}}$ was obtained and subjected to a comparative analysis. Strain YIM $70010^{\mathrm{T}}$ was phylogenetically most closely related to C. muralis DSM $14442^{\mathrm{T}}$, with a $16 \mathrm{~S}$ rRNA gene sequence similarity value of $99 \cdot 6 \%$. The phylogenetic tree (Fig. B) is available as supplementary material in IJSEM Online.

DNA-DNA hybridization between strain YIM $70010^{\mathrm{T}}$ and C. muralis DSM $14442^{\mathrm{T}}$ was carried out by applying the optical renaturation method (De Ley et al., 1970; Huss et al., 1983; Jahnke, 1992) under optimal hybridization conditions. The determined DNA-DNA relatedness value of $56 \%$ (experiment repeated twice) was significantly lower than $70 \%$, which is considered to be the threshold value for the delineation of genomic species (Wayne et al., 1987).

On the basis of phylogenetic, morphological and chemotaxonomic evidence and its physiological and biochemical distinctiveness (Table 1), it is proposed that strain YIM $70010^{\mathrm{T}}$ be classified as Citricoccus alkalitolerans sp. nov.

\section{Description of Citricoccus alkalitolerans sp. nov.}

Citricoccus alkalitolerans (al.ka.li'to.le.rans. Arabic article al the; Arabic n. qaliy ashes of saltwort; Gr. adj. tolerans tolerating; N.L. part. adj. alkalitolerans referring to the ability of the organism to tolerate alkaline media).

Cells are aerobic, Gram-positive, non-motile, non-sporeforming cocci, of about $0 \cdot 5-0 \cdot 8 \mu \mathrm{m}$ in diameter. Colonies 
on PYES medium are light yellow, circular, entire, somewhat convex, opaque and approximately $1.5 \mathrm{~mm}$ in diameter after $24 \mathrm{~h}$ at $28^{\circ} \mathrm{C}$. Growth occurs between 10 and $37^{\circ} \mathrm{C}$ with an optimal growth temperature of $28^{\circ} \mathrm{C}$; no growth is observed at 4 or $40{ }^{\circ} \mathrm{C}$. Optimum growth $\mathrm{pH}$ and $\mathrm{NaCl}$ concentration are $8 \cdot 0-9 \cdot 0$ and $0-5 \%$, respectively. Catalasepositive and oxidase-negative. Urease- and tyrosinasenegative. Tweens 20 and 80, casein and starch are not decomposed. $\mathrm{H}_{2} \mathrm{~S}$ production and indole production are negative. Nitrate is not reduced to nitrite. Activities for lipase and $\alpha$-glucosidase are positive. Negative for ornithine decarboxylase, arginine dihydrolase, lysine decarboxylase, $\beta$-glucuronidase, $\alpha$-and $\beta$-galactosidase, $N$-acetyl- $\beta$-glucosaminidase and $\beta$-glucosidase. The following substrates are utilized as sole carbon sources for growth (with no acid production): glucose, galactose, sucrose, arabinose, mannose, mannitol, maltose, starch, xylose, ribose, cellobiose, salicin, sorbitol, lactose, dextrin, amygdalin, glycine and lysine. Fructose, $N$-acetyl- $\alpha$-glucosamine, L-alanine, $\beta$ alanine, L-histidine, L-ornithine, L-tryptophan and arginine are not utilized. The peptidoglycan is of the Lys-Gly-Glu type (variation $\mathrm{A} 4 \alpha$ ). The predominant menaquinone is MK-9 $\left(\mathrm{H}_{2}\right)$ and the cellular polar lipids are diphosphatidylglycerol, phosphatidylglycerol, phosphatidylinositol and two unknown glycolipids. The cellular fatty acids are anteiso- $\mathrm{C}_{15: 0}(74 \cdot 58 \%)$, iso- $\mathrm{C}_{15: 0}(13 \cdot 14 \%)$, anteiso$\mathrm{C}_{17: 0}(3.94 \%)$, iso- $\mathrm{C}_{16: 0}(1 \cdot 78 \%), \mathrm{C}_{15: 0}(1.69 \%)$, iso$\mathrm{C}_{14: 0}(1 \cdot 14 \%)$, iso- $\mathrm{C}_{13: 0}(0 \cdot 3 \%)$, iso- $\mathrm{C}_{17: 0}(0 \cdot 85 \%)$, anteiso- $\mathrm{C}_{13: 0}(0 \cdot 9 \%), \mathrm{C}_{13: 0}(0 \cdot 14 \%), \mathrm{C}_{14: 0} \quad(0 \cdot 68 \%)$, $\mathrm{C}_{13: 0}(0 \cdot 14 \%)$ and $\mathrm{C}_{16: 0}(0 \cdot 86 \%)$. The DNA G $+\mathrm{C}$ content is $63 \cdot 8 \mathrm{~mol} \%$.

The type strain, YIM $70010^{\mathrm{T}}\left(=\right.$ CCTCC AA $203008^{\mathrm{T}}=$ DSM $15665^{\mathrm{T}}=$ KCTC $19012^{\mathrm{T}}$ ), was isolated from an alkaline soil sample collected from the eastern desert of Egypt.

\section{Acknowledgements}

The authors would like to thank Professor R. M. Kroppenstedt and Dr R. Pukall for kindly providing the type strain of C. muralis (DSM $14442^{\mathrm{T}}$ ) and Dr Peter Schumann for help with the peptidoglycan analysis. This research was supported by the National Basic Research Program of China (2004CB719600), Chinese National Natural Science Foundation (30270004), Yunnan Provincial Natural Science Foundation (2001C0001Q and 2004C0002Q), Yunnan Education Commission Foundation (02QJ077), China and the 21C Frontier Microbial Genomics and Application Center Program, Minister of Science \& Technology (MG02-0101-002-1-0-0), the International Cooperation R \& D Program, Minister of Science \& Technology (M6-0203-000002), Korea.

\section{References}

Altenburger, P., Kämpfer, P., Schumann, P., Steiner, R., Lubitz, W. \& Busse, H.-J. (2002a). Citricoccus muralis gen. nov., sp. nov., a novel actinobacterium isolated from a medieval wall painting. Int $J$ Syst Evol Microbiol 52, 2095-2100.

Altenburger, P., Kämpfer, P., Schumann, P., Vybiral, D., Lubitz, W. \& Busse, H.-J. (2002b). Georgenia muralis gen. nov., sp. nov., a novel actinobacterium isolated from a medieval wall painting. Int $J$ Syst Evol Microbiol 52, 875-881.
Cui, X. L., Mao, P. H., Zeng, M., Li, W. J., Zhang, L. P., Xu, L. H. \& Jiang, C. L. (2001). Streptimonospora salina gen. nov., sp. nov., a new member of the family Nocardiopsaceae. Int J Syst Evol Microbiol 51, 357-363.

De Ley, J., Cattoir, H. \& Reynaerts, A. (1970). The quantitative measurement of DNA hybridization from renaturation rates. Eur $J$ Biochem 12, 133-142.

DSMZ (2001). Catalogue of Strains, 7th edn. Braunschweig: Deutsche Sammlung von Mikroorganismen und Zellkulturen.

Felsenstein, J. (1985). Confidence limits on phylogenies: an approach using the bootstrap. Evolution 39, 783-791.

Groth, I., Schumann, P., Weiss, N., Martin, K. \& Rainey, F. A. (1996). Agrococcus jenensis gen. nov., sp. nov., a new genus of actinomycetes with diaminobutyric acid in the cell wall. Int J Syst Bacteriol 46, 234-239.

Huss, V. A. R., Festl, H. \& Schleifer, K.-H. (1983). Studies on the spectrophotometric determination of DNA hybridization from renaturation rates. Syst Appl Microbiol 4, 184-192.

Jahnke, K.-D. (1992). BASIC computer program for evaluation of spectroscopic DNA renaturation data from Gilford System 2600 spectrophotophotometer on a PC/XT/AT type personal computer. J Microbiol Methods 15, 61-73.

Kimura, M. (1980). A simple method for estimating evolutionary rates of base substitutions through comparative studies of nucleotide sequences. J Mol Evol 16, 111-120.

Kimura, M. (1983). The Neutral Theory of Molecular Evolution. Cambridge: Cambridge University Press.

Kroppenstedt, R. M. (1982). Separation of bacterial menaquinones by HPLC using reverse phase (RP 18) and a silver loaded ion exchanger as stationary phases. J Liquid Chromatogr 5, 2359-2387.

Kroppenstedt, R. M., Korn-Wendisch, F., Fowler, V. J. \& Stackebrandt, E. (1981). Biochemical and molecular genetic evidence for transfer of Actinoplanes armeniacus into the family Streptomycetaceae. Zentbl Bakt Hyg Abt Orig 2, 254-262.

MacKenzie, S. L. (1987). Gas chromatographic analysis of amino acids as the $N$-heptafluorobutyryl isobutyl esters. J Assoc Off Anal Chem 70, 151-160.

Marmur, J. (1961). A procedure for the isolation of deoxyribonucleic acid from microorganisms. J Mol Biol 3, 208-218.

Marmur, J. \& Doty, P. (1962). Determination of base composition of deoxyribonucleic acid from its denaturation temperature. $J$ Mol Biol 5, 109-118.

Minnikin, D. E., O'Donnell, A. G., Goodfellow, M., Alderson, G., Athalye, M., Schaal, A. \& Parlett, J. H. (1984). An integrated procedure for the extraction of isoprenoid quinines and polar lipids. J Microbiol Methods 2, 233-241.

Saitou, N. \& Nei, M. (1987). The neighbor-joining method: a new method for reconstructing phylogenetic trees. Mol Biol Evol 4, 406-425.

Sasser, M. (1990). Identification of bacteria by gas chromatography of cellular fatty acids. USFCC Newsl 20, 16.

Sato, M., Beppu, T. \& Arima, K. (1983). Studies on antibiotics produced at high alkaline pH. Agric Biol Chem 47, 2019-2027.

Schleifer, K. H. (1985). Analysis of the chemical composition and primary structure of murein. Methods Microbiol 18, 123-156.

Schleifer, K. H. \& Kandler, O. (1972). Peptidoglycan types of bacterial cell walls and their taxonomic implications. Bacteriol Rev 36, 407-477.

Shirling, E. B. \& Gottlieb, D. (1966). Methods for characterization of Streptomyces species. Int J Syst Bacteriol 16, 313-340. 
Thompson, J. D., Gibson, T. J., Plewniak, F., Jeanmougin, F. \& Higgins, D. G. (1997). The CLUSTAL_X windows interface: flexible strategies for multiple sequence alignment aided by quality analysis tools. Nucleic Acids Res 25, 4876-4882.
Wayne, L. G., Brenner, D. J., Colwell, R. R. \& 9 other authors (1987). International Committee on Systematic Bacteriology. Report of the ad hoc committee on reconciliation of approaches to bacterial systematics. Int J Syst Bacteriol 37, 463-464. 